EASTERN REVIEW 2020, T. 9

\author{
Michat Kumor \\ (iD https://orcid.org/0000-0002-1099-5051 \\ AGH University of Science and Technology, Cracow, Poland \\ Faculty of Energy and Fuels \\ e-mail:mickum@agh.edu.pl \\ Stanisław Porada \\ (iD https://orcid.org/0000-0001-5290-6523 \\ AGH University of Science and Technology, Cracow, Poland \\ Faculty of Energy and Fuels \\ e-mail: porada@agh.edu.pl
}

\title{
A common gas market for Visegrad Group countries
}

\begin{abstract}
The construction of the North-South Gas Corridor, regional energy integration and international cooperation in the Visegrad Group (Poland, Hungary, Czech Republic and Slovakia) can be determinants for the creation of a common gas market for four Eastern Europe countries (V4). The starting point for this work is concerned with the technical possibilities, chances, threats and necessary steps for the development of the existing infrastructure. The import capacities of countries neighbouring the V4 territory and the internal gas transmission potential inside the indicated group of countries have been presented in this paper. Special attention was paid to the international possibilities of using underground gas storage. The V4 countries, in particular, were examined due to their location between the Russian Federation and Western European gas consumers, and due to the need to ensure the security of supply, volumes and directions of import and export for each from. The bringing online of the gas connection between Norway and Poland, along with the construction of the Croatian LNG terminal, and the establishment of a common gas market for deliveries inside V4 may significantly contribute to determining a new physical direction of the gas flow in this part of Europe.
\end{abstract}

Keywords: gas market, natural gas, Visegrad Group. 


\section{Introduction and aim of the study}

The idea of building the North-South Gas Corridor (Trubalska, 2016: 191-20) connecting the Baltic Pipe, the LNG terminal in Swinoujscie with the Czech Republic, Slovakia, Hungary and the planned Croatian LNG terminal and also the technical start of the first cross-border gas market in northern Europe (Jakstas, 2019: 10; Wyganowski, 2019) may lead to the implementation of a similar solution in the region around Poland. International cooperation between Poland, the Czech Republic, Hungary and Slovakia is mainly based on the Visegrad Group - V4 political alliance (Hudec, 2016: 26-35). Cooperation within the framework of V4 is focused primarily on increasing the level of regional integration. Energy integration, including the natural gas (NG) market, should be a basic element of the aforementioned regional integration. The creation of a new international common market, inspired by the Finnish-Estonian-Latvian solution, would allow for the easy and free trade of natural gas within an area inhabited by nearly 64 million people (Schmidt, 2017: 113-140). Combining 4 countries into one macro-area would allow to optimize tariff costs on cross-border connections, increase the availability of underground gas storage facilities and facilitate access to potential fuel suppliers from countries with which V4 participants are not directly connected.

The aim of this article is to analyse the possibility of creating a common natural gas market and gas balancing area in Central and Eastern Europe, based on the Visegrad Group. The presented work aims at 1) indicating development opportunities for such a market; 2) assessing its strengths and weaknesses; as well as 3) identifying necessary infrastructure investments. The paper is analytical and combines many data sources.

\section{Methods of research and analysis}

The analysis carried out focused on three aspects of high-methane gas transmission and consumption, i.e.: transmission systems' technical capacities and the main directions of NG physical flow; the demand for fuel in each of the V4 member countries; and the possibility of storing gas in underground gas storage facilities (UGS).

The first step covers aggregating import abilities through the interconnection of entry points to transmission systems in Poland, Czech Republic, Slovakia and Hungary from neighbouring countries. Two different directions of NG deliveries were indicated - "western" from European Union countries and "quasi-eastern" (Romania is EU member, but is located on the eastern border of V4) from non-EU 
members like Ukraine and Belarus. Data concerning gas transmission possibilities and technical capacities within V4 countries were essential for carrying out this analysis. Measurements and data used in the first part of the article are published in the official ENTSOG database - European Network of Transmission System Operators for Gas (European Network..., 2020).

The second section of this paper focuses on analysing the current demand of member countries for natural gas. This part of the article is based on fuel demand, regardless of the direction of its origin.

The final stage of the research constitutes an analysis of the potential use of underground gas storage facilities, in particular for facilities covered by the rules on TPA (Third-party access) and for operators affiliated with GSE - Gas Storage Europe (Gas Infrastructure Europe, 2020).

For full and complex analysis it is necessary to indicate the price changes of gas products available on regulated trading platforms and also their interdependency. Short term supply market - SPOT, with delivery during the day after the transaction day (Day Ahead) (Zajdler, 2014) was used as a product that reflects the prevailing moods and trends on the indicated markets best. For the purpose of this work, the period between 1.01.2016 and 1.01.2020 was analysed. Market regulations and legal issues were not a part of this study.

\section{Transmission systems characteristics}

\section{Countries network characteristics}

\section{Poland}

The high-pressure natural gas transmission network in Poland can be described as three cooperating subsystems. The first and best-known subsystem is the transit gas pipeline YAMAL, which is a gas bridge connecting the Russian Federation with the European Union. The entry point to the Polish part of YAMAL, and at the same time the EU import point, is Kondratki (1P). The exit point from Polish territory is located in Mallnow (2P). The Polish section of the transit pipeline is $683,9[\mathrm{~km}]$ long and connected to the NG high-methane transmission system by the Punkt Wirtualnego Polaczenia (PWP). PWP is a virtual combination of two physical hydraulic connectors in Lwowek (3P) and Wloclawek (4P) (Ruszel, 2017: 5-22). The second subsystem - the NG high-methane transmission system - is the main transmission network in Poland. The network is physically connected to the transmissions systems of neighbouring countries: Belarus (Wysokoje) (5P), Ukraine (Hermanowice/Drozdowicze) (6P), Czech Republic (Cieszyn) (7P), Germany (Lasow) (8P), Gubin (9P), Kamminke (10P). The three last interconnection points, which connect with the German 
transmission system, are working together to form a virtual point called GCP - Grid Connection Point (Platforma informatyczna GAZ-SYSTEM..., 2018). It is worth noting that hydraulic connections with the Czech Republic, Germany and Ukraine are bi-directional, entry/exit points, which makes import and export of NG possible. The Polish transmission network is connected with the LNG terminal in Swinoujscie (11P) - "gas window" to the world. It is a unique facility for the whole V4 territory and is definitely an advantage for the transmission system, which is connected to the worldwide LNG market now. Figure 1 presents another entry point (12P) called Tietierowka, which is a supply point for the distribution system and has local importance. The third subsystem located on the territory of the biggest V4 member is a low-methane NG transmission system. Low-methane and high-methane transmission systems are hydraulically connected by blending-plants and nitrogen-removal plants.

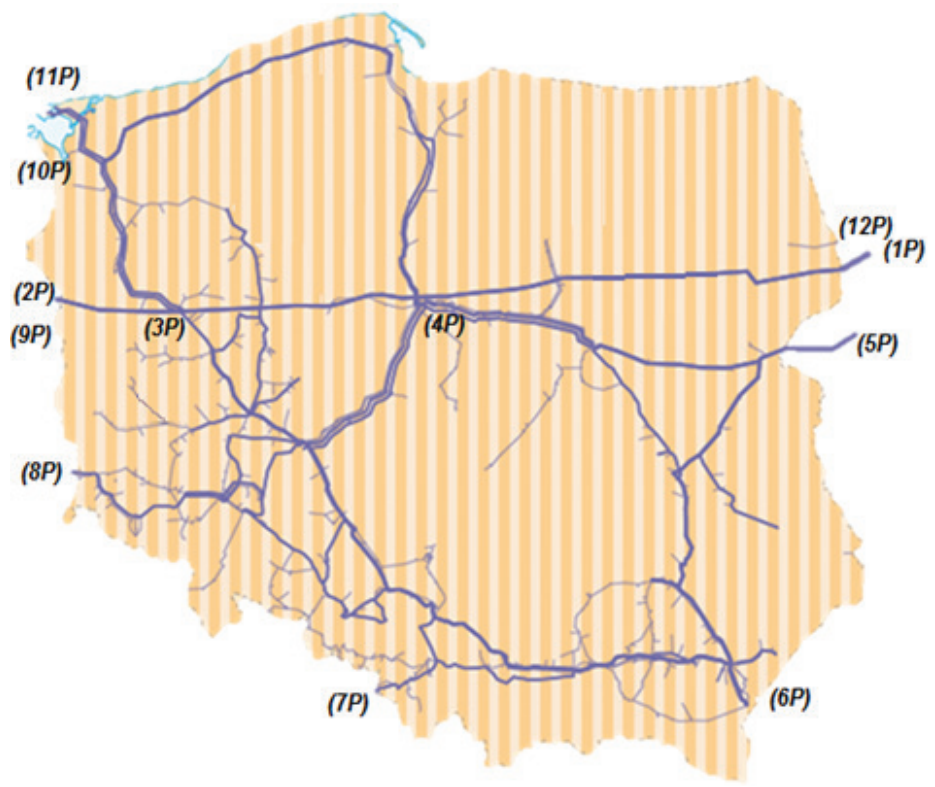

Figure 1. The natural gas transmission system in Poland Sources: European Network..., 2020

The Polish gas transmission system is dominated by supplies from the east and from the LNG terminal. The Polish transmission system operator (TSO) is building an interconnection point with Slovakia (Budowa gazociagu Polska-Stowacja..., 2019). The technical capacities, and the physically transmitted volumes of NG through the Poland-Czech Republic interconnection point are presented in Figure 2. Based on the presented data, it can be concluded that this point, despite the possibility of a reverse-flow transmission service, works only as an import point to Poland 
from the Czech Republic. Deliveries through the connection point with the Czech Republic are characterized by an intensity of use during the winter season. The Cieszyn point has become more popular and has been frequently used since the 2017/2018 winter season. It was only used on a few single days before that date.

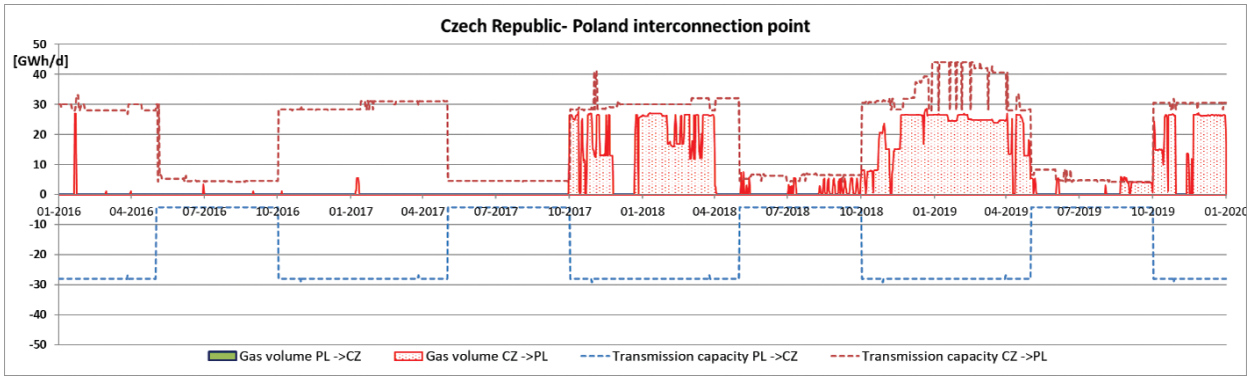

Figure 2. The utilisation rate of the Cieszyn interconnection point Sources: European Network..., 2020.

\section{Czech Republic}

The Czech transmission network is hydraulically connected with three neighbouring countries. The interconnection point with Poland (Cieszyn) (1C) is described above, whilst the connection point with Slovakia is located in Lanzhot (2C) and was built according to a bi-directional idea.

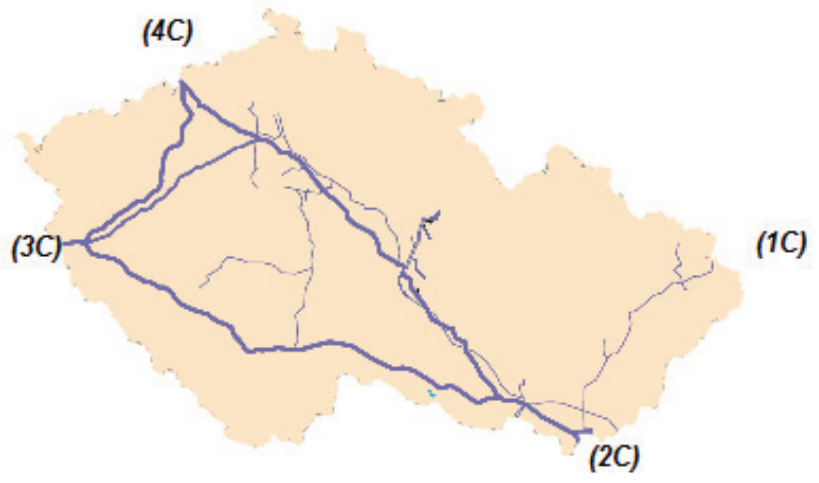

Figure 3. The natural gas transmission system in the Czech Republic Sources: European Network..., 2020.

The western border of the Czech Republic is more interesting because it is connected to German gas pipelines at two points. The connection to the NCG German market area was constructed in Waidhaus (3C) and is primarily a fuel export point. NG is transmitted to the Czech Republic from the second German 
market GASPOOL via OPAL and STEGAL gas pipelines, these are connected to the Czech system through points near Hora Sv. Katerina (4C). Access to the German gas markets and high-capacity inter-connectors provide an opportunity for the development of a competitive gas market beyond the eastern German border.

Whilst describing the Czech transmission network, one must also mention that the underground gas storage facility located in the Czech Republic is connected with the Slovak transmission system in Dolni Bojanowice.

\section{Hungary}

The Hungarian high-pressure natural gas transmission network is presented in Figure 4. Similarly to the Polish system, it is connected with two non-EU countries i.e. Ukraine and Serbia. At the border with Ukraine, two interconnections were built, the larger one called Beregdaroc/Beregovo $(1 \mathrm{H})$ functions as an import point, and the other one $(2 \mathrm{H})$ has the main task of exporting gas in an eastern direction. Another cross-border connection point, Csanadpalota $(3 \mathrm{H})$, was designed and built with bi-directional technology, but it is usually used as an export point to Romania. Serbia is connected to, and supplied from, the Hungarian network by the Kiskundorozsma $(4 \mathrm{H})$ exit point. The interconnection point with Croatia in Dravaszerdahely $(5 \mathrm{H})$ was extended at the beginning of 2020 and since then it provides for the import of gas fuel from the south.

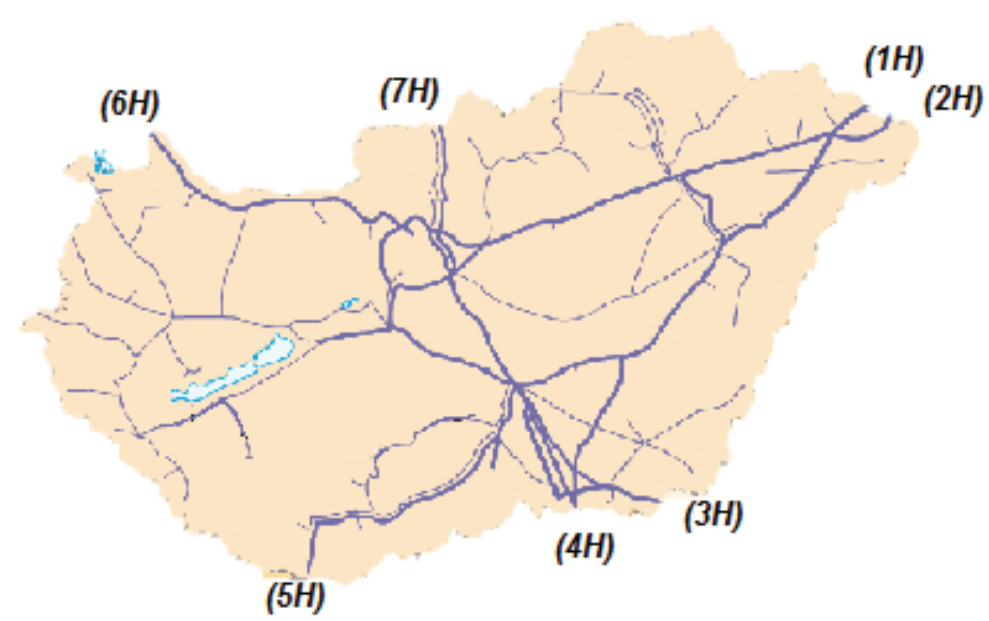

Figure 4. The natural gas transmission system in Hungary

Sources: European Network..., 2020.

It is worth noting that the most important entry point, and one used at almost full capacity, is located at the Austrian border - Mosonmagyarovar $(6 \mathrm{H})$. The last point on the map is the reverse connection with Slovakia - Balassagyarmat/ Velke Zlievce $(7 \mathrm{H})$. The Hungarian gas transmission system is dominated by 
supplies from Ukraine. The other main entry points are located in the north of the country and are also supplied from the east, which is strongly reflected in the maximum fulfilment level of high methane storage facilities. This is in part due to the looming threat of transit interruption through the territory of Ukraine (Ruszel, 2015: 49-58). Technical capacities, and physically transmitted volumes of NG through the Hungary-Slovakia interconnection point are presented in Figure 5.

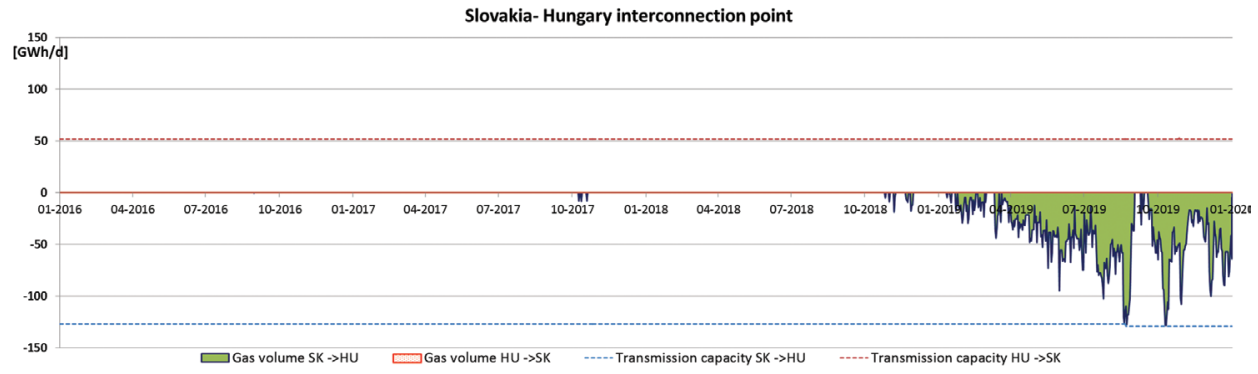

Figure 5. The utilisation rate of the Balassagyarmat/Velke Zlievce interconnection point Sources: European Network..., 2020.

The collected data may indicate that the Balassagyarmat/Velke Zlievce interconnection point is used by Hungarians as an import point, despite the possibility of changing the direction of transmission. The technical infrastructure allows for the flow of a maximum capacity of $1,8\left[\mathrm{bln} \mathrm{m}^{3} /\right.$ year $]-20,088[\mathrm{TWh} /$ year] in the northern direction as well.

\section{Slovakia}

The Slovak natural gas transmission network is presented in Figure 6 . It probably is the simplest and least expansive system of all V4 countries. However, it is worth remembering that the well-developed gas distribution network makes Slovakia the second-best gasificated country in Europe (the Netherland has the highest gasification rate) with high natural gas availability for end-users (SPP - distribúcia..., 2020). The reverse gas interconnection point with Ukraine - Velke Kapusany (1S) is equipped with the largest compressor station in Europe, which can be described as the beginning of the largest land route for the transmission of Russian fuel to Western Europe (160 years of gas industry..., 2016). A second interconnection point - Budince (2S) - is located right next to Velke Kapusany and works as an export point. A bi-directional connection point with Hungary - Velke Zlievce (3S) was built in 2014 and it began operating commercially during the second half of 2015. This entry/ exit point was used only occasionally before 2019 when its utilization was significantly intensified. 


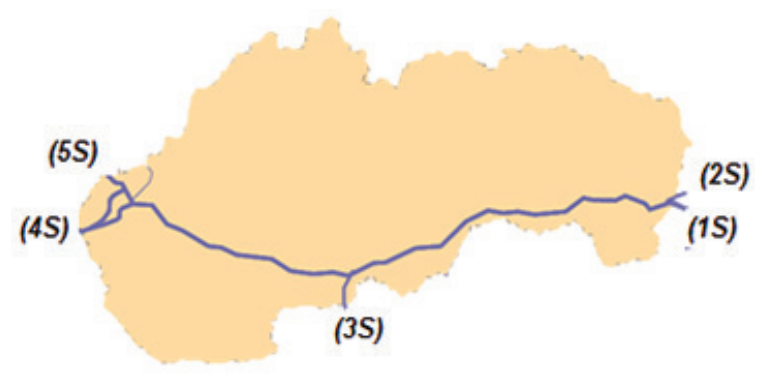

Figure 6. The natural gas transmission system in Slovakia Sources: European Network..., 2020.

Two bi-directional hydraulic connections: Baumgarten with Austria (4S) and Lanzhot with the Czech Republic (5S), are located at the Western Slovak border. Cross- border connection with Austria operates mainly as an export point for NG injected at the Velke Kapusany, and it is a supply point for the largest gas hub in Europe, from which fuel goes through Austria to Germany, Italy, Slovenia and Hungary. Transmitted volumes and directions of NG through the Czech Republic interconnection point are presented in Figure 7.

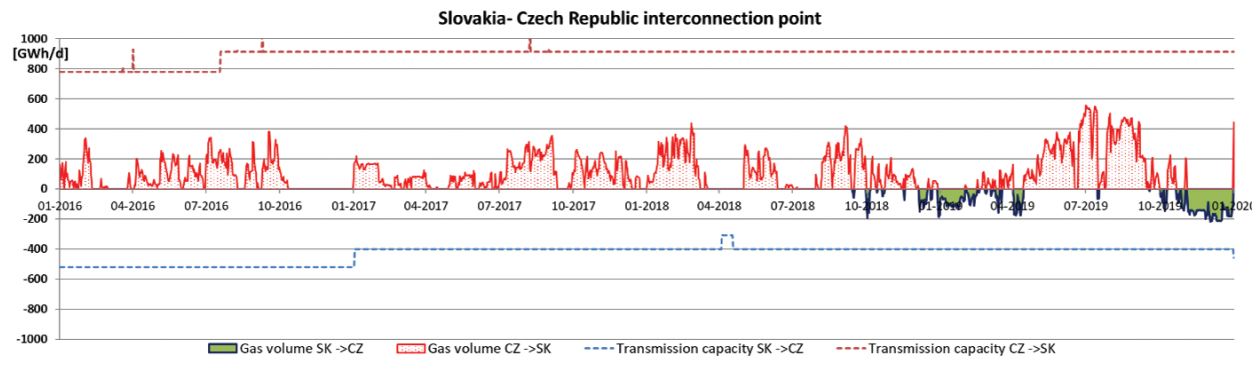

Figure 7. The utilisation rate of the Lanzhot interconnection point Sources: European Network..., 2020.

It should be noted that the technical capacities of the Lanzhot point are being used only partially and mainly as an import point for the Slovak network. This connection has only occasionally worked in the reverse direction, with particular emphasis on the winter months of 2018 and 2019.

\section{Currently available and planned cross-border interconnection points with members of the European Union}

Possible V4 import volumes are presented in Table 1. Natural gas supply from EU countries, which are not V4 members, is mainly possible from the West, but it should be kept in mind that cross-border connection with Romania also 
exists. It should be pointed out that YAMAL pipeline can be used in the reverse direction to transmit fuel from Germany.

Table 1. Parameters of accessible gas network interconnection points with EU countries

\begin{tabular}{|c|c|c|c|c|c|}
\hline Point & Supplier & Recipient & $\begin{array}{l}\text { Technical } \\
\text { capacity } \\
{[G W h / d]}\end{array}$ & 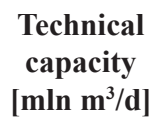 & $\begin{array}{c}\text { Reference } \\
\text { GCV } \\
{\left[\mathbf{k W h} / \mathbf{m}^{3}\right]}\end{array}$ \\
\hline Mallnow & Germany & Poland & 184,8 & 16,682 & 11,078 \\
\hline GCP & Germany & Poland & 48,7 & 4,368 & 11,150 \\
\hline Hora Sv. Kateřiny & Germany & Czech Rep. & 287,7 & 25,644 & 11,219 \\
\hline Hora Sv. Kateřiny & Germany & Czech Rep. & 95,0 & 8,471 & 11,219 \\
\hline Brandov & Germany & Czech Rep. & 951,9 & 85,065 & 11,190 \\
\hline Baumgarten & Austria & Slovakia & 246,5 & 22,088 & 11,160 \\
\hline Mosonmagyarovar & Austria & Hungary & 153,1 & 13,609 & 11,250 \\
\hline Dravaszerdahely & Croatia & Hungary & 12,1 & 0,990 & 12,270 \\
\hline Csanadpalota & Romania & Hungary & 21,5 & 1,951 & 11,020 \\
\hline TOTAL & $\mathbf{E U}$ & V4 & 2001,4 & 178,867 & 11,189 \\
\hline
\end{tabular}

Sources: European Network..., 2020.

The maximal reverse transmission possibilities of the YAMAL pipeline is limited by the measuring system located at the PWP entry/exit point; which is the actual import point for the Polish transmission network. As technical capacities of PWP are still higher than the Mallnow entry point, Mallnow has been listed in Table 1 as an import bottleneck.

Some new cross-border interconnections are planned to be built and launched during the next few years. They may serve as new alternative sources of natural gas supply for the gas markets of the V4 members. In the northern part of the region gas connections between Poland and Lithuania (GIPL pipeline) and Denmark-Norway (Baltic Pipe) (Gas Interconnection Poland-Lithuania..., 2012) are under construction. These investments are part of the North-South Gas Corridor. In the south, an expansion of the Romania-Hungary cross-border point is planned. The aforementioned investment in interconnections, and the planned construction of the Hungary-Slovenia-Italy pipeline (FGSZ International Projects, 2020), are important elements of the East-West Gas Corridor. 
The currently available and planned cross-border transmission network interconnection points with non-European Union countries

To broaden the analysis of import capacities, data published by ENSTSOG were used. Technical parameters of import points are presented in Table 2.

Table 2. Parameters of accessible gas network interconnection points with non-EU countries

\begin{tabular}{|l|c|c|c|c|c|}
\hline \multicolumn{1}{|c|}{ Point } & Supplier & Recipient & $\begin{array}{c}\text { Technical } \\
\text { capacity } \\
{[\mathbf{G W h} / \mathbf{d}]}\end{array}$ & $\begin{array}{c}\text { Technical } \\
\text { capacity } \\
{\left[\mathbf{m l n} \mathbf{~ m}^{\mathbf{3} / \mathbf{d}]}\right.}\end{array}$ & $\begin{array}{c}\text { Reference } \\
\mathbf{G C V}\left[\mathbf{k W h} / \mathbf{m}^{3}\right]\end{array}$ \\
\hline Terminal LNG & World & Poland & 158,0 & 13,680 & 11,550 \\
\hline Tietierowka & Belarus & Poland & 7,3 & 0,648 & 11,270 \\
\hline PWP & Yamal & Poland & 275,5 & 24,869 & 11,078 \\
\hline Wysokoje & Belarus & Poland & 169,1 & 15,005 & 11,270 \\
\hline Drozdowicze & Ukraine & Poland & 135,6 & 12,000 & 11,300 \\
\hline Velke Kapusany & Ukraine & Slovakia & 2028,0 & 181,720 & 11,160 \\
\hline Budince & Ukraine & Slovakia & 249,6 & 22,366 & 11,160 \\
\hline Beregdaróc & Ukraine & Hungary & 526,6 & 45,839 & 11,410 \\
\hline TOTAL & NON-EU & $\mathbf{V 4}$ & $\mathbf{3 5 4 9 , 7}$ & $\mathbf{3 1 6 , 1 2 7}$ & $\mathbf{1 1 , 2 2 9}$ \\
\hline
\end{tabular}

Sources: European Network..., 2020.

Tietierowka is the smallest entry point used by a local group of end-users near Bialystok city. The biggest point, Velke Kapusany, supplies the transmission line to Western Europe. Budince on the Ukraine-Slovakia border currently fulfils the role of an export point towards Ukraine and despite bi-directional technology provides no import nowadays.

The expansion of the LNG terminal in Swionujscie is the only planned investment that should increase connections with suppliers from countries outside of the European Union. Planned investments are focused on building a third cryogenic-storage tank for liquefied gas and increasing vaporization capacities by approximately 79,0 [GWh/d], that is nearly 6,890[mln $\left.\mathrm{m}^{3} / \mathrm{d}\right]$ (Program Rozbudowy terminalu $L N G, 2020$ ).

Carrying out the LNG investment will increase the annual import capacity of the V4 to the level of 117,901 [bln m³/year] corresponding to 1324,476 [TWh/year]. That value however should be corrected by the Velke Kapusany capacity, which is mainly dedicated to long distant transit. If total transmission possibilities would ignore this cross-border connection, the Visegrad Group supply possibilities will amount to about 51,573 [bln m³/year] equivalent of 584,255 [TWh/year]. 


\section{The currently available and planned cross-border transmission network interconnection points inside V4}

The analysis of active and planned cross-border connections between the Visegrad Group members is necessary, in order to examine the potential common V4 gas market. The current situation on internal borders needs special attention. Only isolated interconnections on Poland-Czech Republic and Slovakia-Hungary borders are ready to use. The transmission capacities look best on the border of Slovakia and the Czech Republic, where two hydraulic connectors with high capacities are working continuously. Table 3 presents the active interconnection points currently used.

Table 3. Parameters of accessible gas network interconnection points inside V4

\begin{tabular}{|l|c|c|c|c|c|}
\hline \multicolumn{1}{|c|}{ Point } & Supplier & Recipient & $\begin{array}{c}\text { Technical } \\
\text { capacity } \\
{[\mathbf{G W h / d ]}}\end{array}$ & $\begin{array}{c}\text { Technical } \\
\text { capacity } \\
{\left[\mathbf{m l n} \mathbf{~ m}^{\mathbf{3} / \mathbf{d}]}\right.}\end{array}$ & $\begin{array}{c}\text { Reference } \\
\mathbf{G C V} \\
{\left[\mathbf{k W h} / \mathbf{m}^{3}\right]}\end{array}$ \\
\hline Cieszyn & Czech Rep. & Poland & 28,9 & 2,576 & 11,220 \\
\hline Lanzhot & Czech Rep. & Slovakia & 913,7 & 81,873 & 11,160 \\
\hline Dolni Bojanowice* & Czech Rep. & Slovakia & 95,6 & 8,566 & 11,160 \\
\hline Lanzhot & Slovakia & Czech Rep. & 400,4 & 35,878 & 11,160 \\
\hline Dolni Bojanowice* & Slovakia & Czech Rep. & 74,3 & 6,658 & 11,160 \\
\hline Balassagyarmat & Slovakia & Hungary & 127,0 & 11,380 & 11,160 \\
\hline TOTAL & V4 & V4 & $\mathbf{1 4 7 0 , 0}$ & $\mathbf{1 3 1 , 7 0 7}$ & $\mathbf{1 1 , 1 6 1}$ \\
\hline
\end{tabular}

* Capacity used for underground storage facility, not for transmission.

Sources: European Network..., 2020.

There is a plan to expand the Cieszyn cross-border connection, which may reach the transmission capacity in the Czech direction of equal to 5,0 [bln $\mathrm{m}^{3} /$ year $]-56,100$ [TWh/year], and 6,5 [bln $\mathrm{m}^{3} /$ year] - 72,930 [TWh/year] in the opposite direction. Once construction has finished, the Polish-Slovak inter-connector may enable gas transmission in a southernly direction of $4,7\left[\mathrm{bln} \mathrm{m}^{3} /\right.$ year] $-52,452[\mathrm{TWh} /$ year] capacity, and 5,7 [bln $\mathrm{m}^{3} /$ year] - 63,612 [TWh/ year] in a northernly direction.

In February 2020 the Slovak and Hungarian governments signed an agreement on increasing the cross-border connection capacity by up to 5,3 [bln $\mathrm{m}^{3} /$ year] - 59,148 [TWh/year] in both directions. Previous press information mentioned bi-directional capacities of the level of even 7 [bln m³/year] (Hungary, Slovakia sign MoU..., 2020; Hungary \& Slovakia to Boost Gas..., 2019). Slovak-Hungarian inter-connector development is particularly important regarding the possible TurkStream gas usage in the V4 territory.

The aforementioned investments aim to significantly improve the bottlenecks on the Slovak-Polish and Czech-Polish borders. 


\section{Natural gas consumption}

The Visegrad Group's natural gas consumption during the last 8 years (covered in the global BP Statistical Review data report - BP Statistical Review..., 2018) was stable and oscillated around the level of 40 [bln $\mathrm{m}^{3} /$ year]. BP data published in a volumetric measurement unit were converted to energy units using the GCV reference as detailed in Table 3. The V4 average demand after recalculation corresponds to 446,723 [TWh/year]. The annual consumption expressed in TWh broken down by group members is presented in Table 4 .

Table 4. Annual natural gas demand inside V4 - [TWh]

\begin{tabular}{|l|r|r|r|r|r|r|r|r|}
\hline \multicolumn{1}{|c|}{ Country } & \multicolumn{1}{c|}{$\mathbf{2 0 1 1}$} & \multicolumn{1}{c|}{$\mathbf{2 0 1 2}$} & \multicolumn{1}{c|}{$\mathbf{2 0 1 3}$} & \multicolumn{1}{c|}{$\mathbf{2 0 1 4}$} & \multicolumn{1}{c|}{$\mathbf{2 0 1 5}$} & \multicolumn{1}{c|}{016} & \multicolumn{1}{c|}{$\mathbf{1 0 1 7}$} & \multicolumn{1}{c|}{$\mathbf{2 0 1 8}$} \\
\hline Czech Republic & 88,385 & 88,994 & 90,166 & 80,245 & 84,148 & 91,073 & 93,471 & 89,096 \\
\hline Hungary & 121,806 & 108,708 & 101,343 & 90,623 & 97,220 & 104,202 & 110,875 & 107,259 \\
\hline Poland & 183,627 & 194,417 & 194,318 & 189,889 & 190,840 & 203,773 & 214,072 & 220,304 \\
\hline Slovakia & 60,190 & 56,663 & 62,493 & 48,966 & 50,356 & 50,562 & 53,695 & 51,929 \\
\hline V4 & $\mathbf{4 5 4 , 0 0 7}$ & $\mathbf{4 4 8 , 7 8 2}$ & $\mathbf{4 4 8 , 3 2 0}$ & $\mathbf{4 0 9 , 7 2 3}$ & $\mathbf{4 2 2 , 5 6 4}$ & $\mathbf{4 4 9 , 6 1 1}$ & $\mathbf{4 7 2 , 1 1 3}$ & $\mathbf{4 6 8 , 5 8 8}$ \\
\hline
\end{tabular}

Sources: BP Statistical Review..., 2018.

Polish gas market during the analysed period was characterised by the largest increase of end-user demand. Total country demand in 2018, when the Polish share of the V4 gas market reached $47 \%$, corresponds to $120 \%$ of the 2011 country consumption. Hungary is the second-largest consumer of fuel and accounts for $23 \%$ of the V4 market, but in this case, there has been a $12 \%$ decrease in demand during the past 8 years. A similar trend can be observed in Slovakia, which in terms of area and fuel consumption is the smallest consumer $-11 \%$ of the V4 market. The most stable situation is in the Czech Republic, where both in 2011 and 2018 the market share, in relation to other members, was at 19\%.

\section{Underground gas storage facilities}

At the end of 2019, underground gas storage facilities with a working volume (volume available for commercial use) of 182,626 [TWh] were located in the Visegrad Group territory. Interestingly the lowest storage capacities, located in salt caverns and depleted gas fields, are available in Poland. The ratio of the UGS working volume to the final country consumption was barely at the level of $15 \%$ in 2018 . It is worth pointing out that the biggest gas consumer in the V4 is currently focusing on developing this part of gas infrastructure. Over 
the last 8 years, UGS facilities have been almost doubled, reaching the capacity of 34,356 [TWh]. Hungary has the largest storage capacities (about 69,637 [TWh]). At present investments are not being made to develop fuel storage installations, contrary to Poland. Both Slovakia and Hungary have storage facilities with a capacity exceeding half their annual demand.

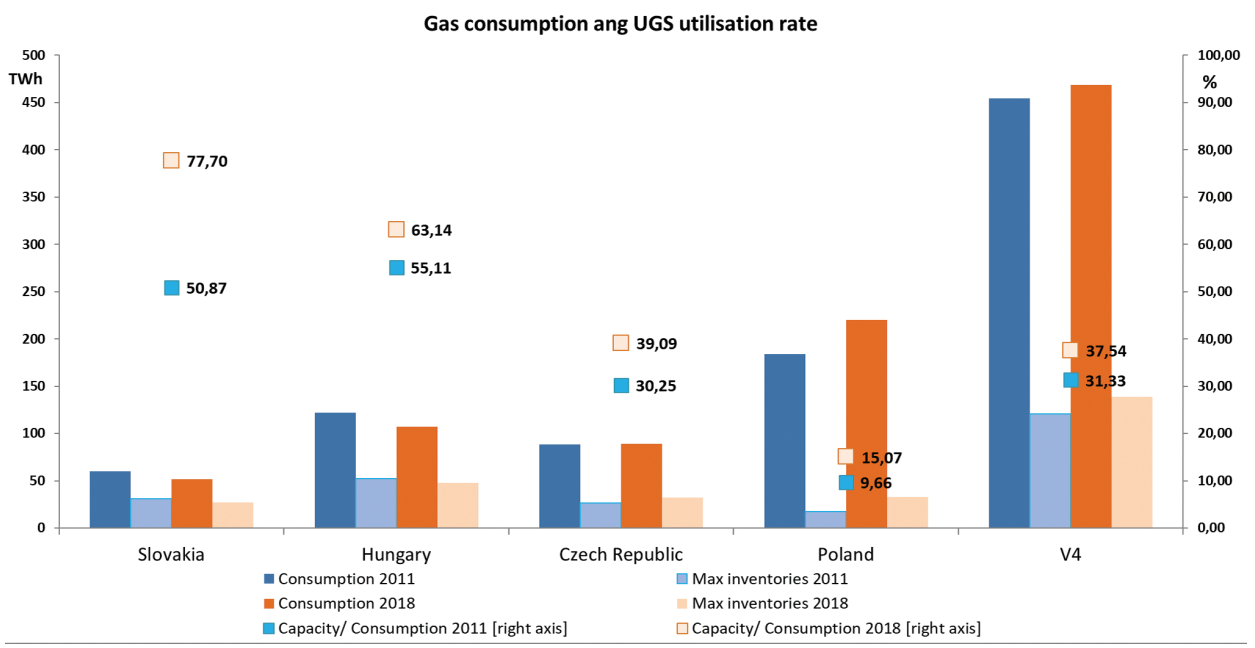

Figure 8. Annual gas consumption and utilisation rate of UGS

Sources: Gas Infrastructure Europe, 2020; BP Statistical Review..., 2018.

It is worth noting that in Slovakia, where full gas storage facilities can cover over $77 \%$ of annual fuel demand, storage system operators are still intensively expanding their working volumes, withdrawal and injection capacities. The Visegrad Group has storage capacities that can satisfy almost $38 \%$ of its annual demand. Data on UGS work parameters and gas consumption are presented in Figure 8.

Storage facilities in the V4 territory have not been fully used over the last 8 years, which is presented in Figure 9. The average stored level at the end of the withdrawal period was close to $23 \%$ and Slovakia had the lowest UGS fulfilment levels. At the end of an injection period, when maximum levels of stored fuel before winter can be reached, the average stock level was close to $82 \%$. Countries with the highest level of stored fuel were Poland and the Czech Republic. "The highest level of unused" volume space remained in the Danube river area, which can be an explanation for both the lack of development of existing infrastructure, as well as any new construction of there. The exception from the presented average situations was the winter of 2019 when due to the uncertain situation regarding the gas transit through the territory of Ukraine, the storage facilities in Slovakia and Hungary were almost $100 \%$ full. 
Underground gas storages play an important role in supplying gas to endusers in all four countries. There are significant differences in the energy policies for the storage of natural gas between the Visegrad Group countries; some of them are the results of geological circumstances.

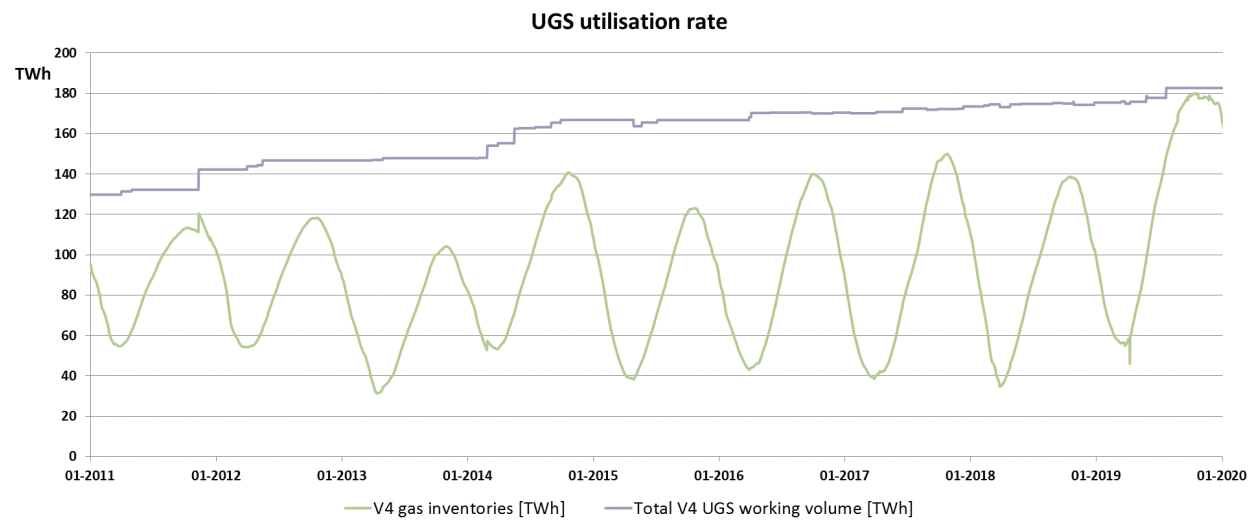

Figure 9. Working curve and utilisation rate of UGS working volume Sources: Gas Infrastructure Europe, 2020.

It is necessary to underline that energy and natural gas cooperation in the scope of storage facilities among V4 countries is still peripheral (Skrzyński, 2020: 21-40).

\section{High-methane natural gas prices on Visegrad Group markets}

The biggest gas market closest to the V4 territory is definitely the German gas hub. Prices of short-term gas products quoted on GASPOOL and NCG markets can be used as benchmarks for NG prices on organized trading platforms in the Czech Republic, Hungary and Poland. Price changes in those markets during the last four years are presented in Figure 10. The graph clearly shows that all prices are closely related. As expected, the natural gas SPOT products with the lowest prices were available in Germany. High transmission capacities on Czech cross-border interconnections and the proximity of the German markets caused the lowest fuel prices among the V4 to be available in the Czech Republic.

Polish and Hungarian markets were only occasionally cheaper than the Czech market during the 1,461 days examined. When comparing TGE (Poland) and CEEGEX (Hungary) prices one should note, that in 53\% of cases TGE indexes were lower. The average difference in SPOT prices amounted to only 0.11 [EUR/MWh].

The creation of a common V4 market may lead to the levelling of prices for all participants, therefore Poland and Hungary have the chance to be the biggest beneficiaries of the new market. 


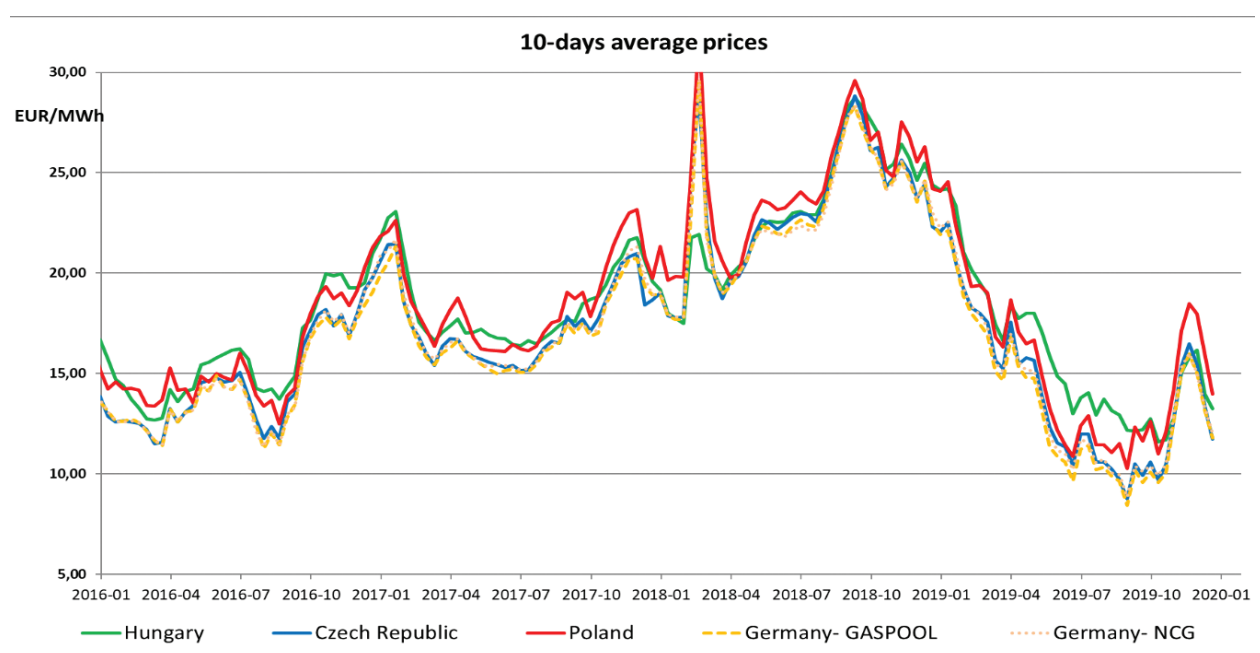

Figure 10. Average prices on SPOT market Sources: OTE Short-Term Markets; POWERNEXT Spot Market Data.

\section{Political and legal background}

The presented data concerns the technical parameters of pipelines and storage systems. Previous studies concerned the political and partnership aspects of regional cooperation. Some authors underlined that the new infrastructure connecting the energy systems of V4 is the first step of building an integrated regional gas market. The V4 common gas market, new infrastructure and regulations will have a positive impact on the Central European region and improve the security of supply (Kochanek, 2019: 19-38). There are several scientific papers concerning the lack of political will of the V4 countries to harmonize their energy policies, which is the foundation of a common gas market. All Visegrad Group members declare common goals related to the supply chain and energy security, but there are no common policy stances shared by all the countries (Jirusek, 2020: 8). A common V4 gas market has to override any particular diverging interests and national policies. The next step is to achieve full market liberalization, which has not been completed in some members countries (Osicka et al., 2018: 184-197).

The first step towards the creation of a common gas market for the Visegrad Group is related to the legal conditions in all member countries. There are three basic elements which should be unified before taking any further measures. It is necessary to set up a common and international institution which will establish concessions for the transmission, distribution and trading for shippers, as well as the fees resulting from them. The second preparatory phase would involve the 
preparation for normalising Transmission Network Codes, and measurements standards e.g. methodologies for the calculation of heating values. The last preparatory phase should redefine the concept of energy security and security of supply which have to be common for all V4 countries.

\section{Conclusions}

Establishing cross-border cooperation leading to a common gas market for countries in Central and Eastern Europe requires a lot of technical, legal and economic analysis. Legal and regulatory analysis has not been described in this work, nevertheless, they are also necessary to define the requirements of a potential V4 common gas market.

Total import technical capacities of the cross-border connections of Visegrad Group participants with non-EU countries exceeds the level of the average demand for natural gas for the entire group. Cross-border connection capacities with EU members are also higher than the average demand, and it is a very favourable situation as it ensures an appropriate level of security and diversification of supply directions. The analysis presented does not take into account domestic production inside the V4, which should further strengthen the positive impact on supply balancing and energy security.

Existing and planned cross-border connections inside the V4 group allow to fully satisfy the gas consumption needs of the Czech Republic and Slovakia. Gas transmission from Visegrad Group members to Poland and Hungary can reach the maximum level, which constitutes almost half of their annual demand. This, in turn, may become a significant problem in the V4 area from the balancing point of view, as the technical capacities at internal borders may not be sufficient to send the fuel purchased at the V4 borders to other member countries (e.g. purchase using Baltic Pipe for Hungarian customers).

Expanding the market may open access to Hungarian storage facilities for shippers and market participants from the Czech Republic and Poland, where UGS facilities are almost at full capacity. Storage facilities in Slovakia have to ensure the security of gas transit, which makes access to them more difficult than to Hungarian UGS facilities.

The potential V4 NG market may reduce the price of available gas products in Poland and Hungary - countries that consume $70 \%$ of the total V4 NG volumes. 


\section{References}

160 years of gas industry in Slovakia, Slovenský plynárenský a naftový zväz. 2016, http:// www.spnz.sk/sk/akcie/akcie-2016.html (accessed 20.03.2020).

BP Statistical Review of World Energy. 2018, https://www.bp.com/en/global/corporate/ energy-economics/statistical-review of-world-energy.html (accessed 7.03.2020).

Budowa gazociagu Polska-Słowacja oficjalnie rozpoczęta. 2019, https://www.gov.pl/ web/aktywa-panstwowe/budowa-gazociagu-polska--slowacja-oficjalnie-rozpoczeta (accessed 1.03.2020).

European Network of Transmission System Operators for Gas. 2020, https://www.entsog. eu/ https://transparency.entsog.eu/ (accessed 11.03.2020).

FGSZ International Projects. 2020, https://fgsz.hu/en/about-fgsz/activities-business-policy/ international-projects/brua (accessed 30.03.2020).

Gas Infrastructure Europe. 2020, https:/www.gie.eu/index.php/transparency/gse-transparency-template (accessed 12.03.2020).

Gas Interconnection Poland-Lithuania (GIPL) Backbone of Regional Market Development, 2012, https://www.lsta.1t/files/seminarai/140226_Lenkijos\%20ambasada/Pranesimai/ 04_sek___gipl.pdf (accessed 1.03.2020).

Hudec, M. 2016. Development of the Visegrad Group in the Context of Efforts to Accelerate the Convergence Processes by Joining the European Union. Studia commercialia Bratislavensia 9/33(1), pp. 26-35.

Hungary \& Slovakia to Boost Gas Interconnector Capacity. 2019, https://industryeurope. com /hungary-slovakia-to-boost-gas-interconnector-capacity/ (accessed 30.03.2020).

Hungary, Slovakia sign MoU on gas interconnector expansion. 2020, https://bbj.hu/energyenvironment/hungary-slovakia-sign-mou-on-gas-interconnector-expansion_178628 (accessed 30.03.2020).

Jakstas, T. 2019. Creation of regional gas market in the Baltic States and Finland: Challenges and opportunities. BSR Policy Briefing series 8, p. 10.

Jirusek, M. 2020. The attitude of the Visegrad Group Countries towards Russian Infrastructural Projects in the gas sector. Energy Policy 139, pp. 1-10.

Kochanek, E. 2019. Regional cooperation on gas security in Central Europe. Polityka Energetyczna - Energy Policy Journal 22(1), pp. 19-38.

Osicka, J., Lehotsky, L., Zapletalova, V., Cernoch, F., Dancak, B. 2018. Natural gas market integration in the Visegrad 4 region: An example tofollow or to avoid? Energy Policy 112, pp. 184-197.

OTE Short-Term Markets, https://www.ote-cr.cz/en/short-term-markets/gas/TGE Rynek Dnia Następnego, https://tge.pl/gaz-rdn (accessed 1.03.2020).

Platforma informatyczna GAZ-SYSTEM do zakupu przepustowości na połączeniach między systemami Polski i Niemiec. 2018, https://www.gaz-system.pl/centrumprasowe/aktualnosci/informacja/artykul/202837/ (accessed 12.02.2020).

POWERNEXT Spot Market Data, https://www.powernext.com/spot-market-data

CEEGEX Day Ahead https://ceegex.hu/en (accessed 1.03.2020).

Program rozbudowy terminalu LNG. 2020, https://www.polskielng.pl/terminal-lng/programrozbudowy-terminalu-lng/ (accessed 30.03.2020). 
Ruszel, M. 2015. Wpływ rosyjsko-ukraińskich kryzysów gazowych na politykę energetyczną UE - ujęcie teoretyczne. Przegląd Politologiczny 2, pp. 49-58.

Ruszel, M. 2017. Ocena bezpieczeństwa dostaw gazu ziemnego do Polski - stan obecny i perspektywa do 2025 r. Polityka Energetyczna 1, pp. 5-22.

Schmidt, A. 2017. Friends forever? The Role of the Visegrad Group and European Integration. Politics in Central Europe 12(3), pp. 113-140.

Skrzyński, M. 2020. The role of underground gas storage facilities in the continuous supply of natural gas to domestic recipients based on the example of the Visegrad Group. Polityka Energetyczna - Energy Policy Journal 23(3), pp. 21-40.

SPP - distribúcia, Słowacki system dystrybucji gazu. 2020, https://www.epinfrastructure. cz/en/activities/gas-power-distribution/ (accessed 20.03.2020).

Trubalska, J. 2016. Trans-european energy infrastructure projects. The case of the northsouth gas corridor. Humanities and Social Science XXI/23(1), pp. 191-202.

Wyganowski, J. 2019. Jednolity (prawie) bałtycki rynek gazu. Energia Gigawat 2, https://www.cire.pl/drukuj,176913,2,jednolity-prawie-baltycki-rynek-gazu.html (accessed 20.03.2020).

Zajdler, R. 2014. Polski rynek hurtowy gazu ziemnego na tle rynków Unii Europejskiej. Warszawa: Robert Zajdler Kancelaria Radcy Prawnego. 